\title{
Percepcja relacji rodzinnych a depresyjność młodzieży z rodzin o różnym typie
}

\section{Perception of family relationships and depressiveness in young people from families of different types}

\author{
Ewa Radoń, Agnieszka Samochowiec ${ }^{\bowtie}$ \\ Uniwersytet Szczeciński, Instytut Psychologii, Zakład Psychologii Klinicznej i Psychoprofilaktyki, ul. Krakowska 69, 71-017 Szczecin \\ $\triangle$ agnieszkasamochowiec@gmail.com
}

\begin{abstract}
Introduction: The aim of the study was to determine the relationship between the perception of family relations and the severity of depression in young people in late adolescence, taking into account the type of family in which they are raised.

Materials and methods: The study involved 120 young people, aged 17-20 years from complete and incomplete (single-parent) families. Applied research tools included a socio-demographic questionnaire, Plopa's Family Relations Questionnaire, and the Beck Depression Inventory.

Results: Performed statistical analyses revealed differences between adolescents raised in complete and incomplete families in terms of their perception of certain family relationships (communication, cohesion, autonomy and identity) and the severity of depression. They also confirmed negative correlations between these variables in subjects from both types of families,
\end{abstract}

except for the identity dimension in the group of adolescents from single-parent families.

Conclusions: The perception of family relations is more positive in adolescents raised in complete families, who also exhibit lower depressiveness than their peers from incomplete families. In both groups, low quality communication, cohesion and autonomy in the family are accompanied by a greater severity of depressive symptoms. These findings are consistent with the concept that characteristics of the family environment constitute either a significant protective factor or promote the onset of depression in adolescents, and can be used in practice when designing prevention and psychoeducational programmes focused on promoting proper relations in the family system, especially if the family is incomplete.

Keywords: adolescence; depressiveness; complete family; incomplete family; family relationships.

\section{ABSTRAKT}

Wstęp: Celem pracy było określenie związku pomiędzy percepcją relacji rodzinnych a nasileniem depresyjności u młodzieży w okresie późnej adolescencji z uwzględnieniem typu rodziny, w której się wychowują.

Materiały i metody: W badaniu uczestniczyło 120 uczniów szkół ponadgimnazjalnych w wieku 17-20 lat, pochodzących z rodzin pełnych oraz niepełnych. Wykorzystane narzędzia badawcze obejmowały ankietę socjodemograficzną, kwestionariusz relacji rodzinnych autorstwa Plopy oraz skalę depresji Becka.

Wyniki: Przeprowadzone analizy statystyczne potwierdziły istnienie różnic pomiędzy młodzieżą z rodzin pełnych a młodzieżą z rodzin niepełnych w zakresie percepcji wybranych relacji rodzinnych (komunikacji, spójności, autonomii i tożsamości) oraz nasilenia depresyjności. Potwierdzono również istnienie ujemnych związków pomiędzy tymi zmiennymi wśród młodzieży
\end{abstract}

z obu typu rodzin, za wyjątkiem wymiaru tożsamości w grupie adolescentów z rodzin niepełnych.

Wnioski: Percepcja relacji rodzinnych jest korzystniejsza u adolescentów z rodzin pełnych, którzy są mniej depresyjni niż ich rówieśnicy z rodzin niepełnych. W obu grupach niskiej jakości komunikacji, spójności i autonomii rodzinnej towarzyszy większe nasilenie objawów depresyjnych. Wnioski te pozostają spójne z koncepcją uznającą właściwości środowiska rodzinnego za znaczący czynnik ochronny lub sprzyjający powstawaniu depresji młodzieńczej oraz mogą znaleźć zastosowanie praktyczne podczas konstruowania programów profilaktycznych i psychoedukacyjnych skoncentrowanych na propagowaniu prawidłowych relacji w systemie rodzinnym, szczególnie o typie niepełnym. Słowa kluczowe: adolescencja; depresyjność; rodzina pełna; rodzina niepełna; relacje rodzinne.

\section{WSTĘP}

Oddziaływanie rodziny na rozwój emocjonalny, społeczny i osobowościowy człowieka zostało szeroko opisane w literaturze przedmiotu $[1,2,3]$. Właściwości środowiska rodzinnego są uznawane za kluczowy czynnik chroniący lub przyczyniający się do powstawania różnego rodzaju zaburzeń psychicznych (np. depresji) w okresie dorastania [4]. Do czynników ryzyka depresji młodzieńczej w szczególności zalicza się nieprawidłowe relacje w rodzinie i wydarzenia o charakterze straty, takie jak rozwód, separacja rodziców lub śmierć któregoś z nich [5]. W społeczeństwie dominuje przekonanie, iż rodzina niepełna musi radzić sobie z większą ilością specyficznych trudności, przez co nie zaspokaja w sposób optymalny 
rozwojowych potrzeb dziecka oraz nie zapewnia tak sprzyjającej i stabilnej atmosfery wychowawczej dla zrównoważonego rozwoju jak rodzina pełna. Badania eksplorujące różnice wśród adolescentów pochodzących z rodzin o odmiennej strukturze potwierdzają, że pochodzenie z rodziny niepełnej jest związane z depresją oraz słabszym emocjonalnym przystosowaniem [6, 7]. Niewątpliwie rozpad rodziny pozostaje dramatycznym wydarzeniem, które ma niekorzystne znaczenie dla zdrowia psychicznego młodzieży.

W literaturze polskiej zespół objawów typowych dla depresji okresu dorastania określany jest terminem depresyjności lub depresji młodzieńczej i jako specyficzne zaburzenie rozwojowe często nie osiąga wymaganego przez systemy diagnostyczne klinicznego nasilenia objawów i zaburzeń funkcjonowania [8]. Bomba [9] w swojej autorskiej koncepcji ujmuje depresję młodzieńczą jako zespół zaburzeń nastroju, emocji, czynności poznawczych i zachowań pojawiających się w konsekwencji trudności w realizacji zadań rozwojowych adolescencji, do których zalicza się osiągniecie emocjonalnej niezależności od dorosłych oraz skonstruowanie spójnego poczucia własnej tożsamości. W piśmiennictwie psychiatrycznym przeważa obecnie stanowisko, że w zakresie podstawowych objawów obraz kliniczny depresji u młodzieży (szczególnie w późnym okresie adolescencji) nie różni się istotnie od obrazu depresji u dorosłych [10]. Według głównego systemu klasyfikacji chorób i zaburzeń psychicznych ICD-10 do kluczowych objawów depresji zalicza się obniżony nastrój, utratę zainteresowań oraz zdolności odczuwania przyjemności. Ponadto w obrazie zaburzenia wystąpić może poczucie beznadziejności, bezwartościowości i nieuzasadnionej winy. Pojawiają się zmiany w zakresie aktywności psychoruchowej, najczęściej w postaci spowolnienia psychoruchowego, utrata energii, męczliwość oraz zmniejszona zdolność do koncentracji uwagi i trudność w podejmowaniu decyzji. Objawy somatyczne obejmują często zaburzenia snu oraz zmniejszenie apetytu [11]. W okresie dorastania specyficzna symptomatologia depresji jest bardzo widoczna. Większość adolescentów mówi o smutku i pustce, choć zamiast tych objawów często dopuszcza się również występowanie rozdrażnienia czy nastroju dysforycznego [12]. Wśród depresyjnych adolescentów odnotowuje się podwyższony poziom lęku, głównie przed przyszłością, zmniejszenie lub brak zainteresowania czynnościami, które wcześniej sprawiały przyjemność, a także pogorszenie relacji z rówieśnikami. Wśród charakterystycznych cech depresyjnej młodzieży znajduje się także impulsywność, negatywizm, społeczna izolacja, poczucie niezrozumienia i osamotnienia [13].

Zbierane w ciągu ostatnich kilkunastu lat dane epidemiologiczne wskazują na wzrost rozpowszechnienia zaburzeń depresyjnych wśród adolescentów oraz obniżenie średniej wieku, w którym pojawiają się one po raz pierwszy. Wśród nastolatków powyżej 12. r.ż. zaburzenie dotyka nawet do 8\% populacji, szczególnie gdy weźmie się pod uwagę subkliniczne jej postacie. Szacuje się, że w wieku 18 lat aż $20 \%$ osób przeszło przynajmniej jeden epizod depresyjny $[5,10,14]$. Większą częstotliwość zapadalności na depresję wieku młodzieńczego odnotowuje się wśród dziewcząt niż chłopców, mimo iż przed okresem adolescencji proporcje te są wyrównane [5, 10, 15]. Badania prowadzone w 2001 r. wśród populacji 17-latków z Gdańska i Koszalina wykazały, że aż 54\% stanowią osoby z objawami depresji [8].

Obecny stan wiedzy pozwala sądzić, że aby rozwinęła się depresja młodzieńcza, musi współwystępować ze sobą wiele czynników natury biologicznej, psychologicznej oraz społeczno-środowiskowej. Wśród tych ostatnich, predysponujących lub podtrzymujących zaburzenie, istotne są zwłaszcza trudności w relacjach rodzinnych. Szczególnie zagrażające są negatywne, odrzucające postawy rodzicielskie oraz dezorganizacja życia rodzinnego poprzez niedostępność opiekunów, a także ich utratę na skutek śmierci, separacji lub rozwodu $[4,5,16,17]$. Szacuje się, że po śmierci rodzica aż $1 \frac{1}{3}$ dzieci może spełniać kryteria epizodu depresyjnego [5]. Badania dotyczące przyczyn depresji młodzieńczej potwierdzają istotnie wyższy poziom symptomów depresyjnych u adolescentów $\mathrm{z}$ rodzin niepełnych w stosunku do tych z rodzin pełnych [2]. Wśród wyzwalających czynników rodzinno-środowiskowych duże znaczenia mają również nieprawidłowe relacje w rodzinie, a zwłaszcza blokowanie naturalnego procesu separacji i indywiduacji młodego człowieka, wynikające często ze starań rodziców w utrzymaniu homeostazy systemu [4]. Surowe praktyki wychowawcze cechujące się nadmierną kontrolą i krytycyzmem, brak akceptacji oraz chłodne i odrzucające relacje z rodzicami zwiększają prawdopodobieństwo występowania u adolescentów depresyjnych symptomów. Polskie badania prowadzone wśród młodzieży w wieku 18-19 lat potwierdzają ujemny związek między zrównoważoną spójnością rodziny a symptomami depresyjnymi, co wskazuje, że odpowiednie relacje w rodzinie mogą być czynnikiem chroniącym przed zaburzeniami depresyjnymi [18]. Zachowaniu zdrowia psychicznego sprzyja atmosfera życia rodzinnego oparta na trosce, zaufaniu i życzliwości oraz otwarta i elastyczna komunikacji w postaci wysłuchiwania poglądów młodego człowieka przez rodziców, a także budowanie partnerskich stosunków umożliwiających zarysowanie własnej odrębności w procesie usamodzielniania się [15, 19, 20]. Obszar bliskich relacji rodzinnych może być dla dorastającego adolescenta źródłem adaptacyjnych zasobów, jak również potencjalnych ograniczeń.

W związku z tym, iż właściwości środowiska rodzinnego uznaje się za fundament prawidłowego rozwoju jednostki oraz czynnik chroniący lub sprzyjający wystąpieniu depresyjności w okresie dorastania, podstawowym celem badań było określenie związku pomiędzy percepcją relacji rodzinnych a nasileniem depresyjności u młodzieży w okresie późnej adolescencji, z uwzględnieniem typu rodziny, w której się wychowują.

Opierając się na wiedzy teoretycznej pochodzącej z literatury przedmiotu oraz na doniesieniach płynących z badań empirycznych, sformułowano następujące hipotezy badawcze:

1. Istnieje różnica pomiędzy młodzieżą z rodzin pełnych a młodzieżą z rodzin niepełnych w zakresie percepcji wybranych wymiarów relacji rodzinnych. 
2. Istnieje różnica pomiędzy młodzieżą z rodzin pełnych a młodzieżą z rodzin niepełnych w zakresie nasilenia depresyjności.

3. Istnieje związek pomiędzy percepcją wybranych wymiarów relacji rodzinnych a nasileniem depresyjności u młodzieży $\mathrm{z}$ rodzin pełnych.

4. Istnieje związek pomiędzy percepcją wybranych wymiarów relacji rodzinnych a nasileniem depresyjności u młodzieży $\mathrm{z}$ rodzin niepełnych.

\section{MATERIAtY I METODY}

W badaniu wykorzystano technikę ankietową z zastosowaniem kwestionariuszy. Analizie poddano dwa typy rodzin - pełne i niepełne, co stanowiło zmienną nominalną. Za wskaźnik typu rodziny uznano odpowiedź zaznaczoną w ankiecie socjodemograficznej. Kolejną zmienną była percepcja relacji rodzinnych, która stanowiła zmienną interwałową. Relacje rodzinne były ujmowane w wymiarze komunikacji, spójności, autonomii i tożsamości. Wskaźnikiem przedstawionych zmiennych były wyniki stenowe uzyskane w wymiarach na podstawie udzielanych odpowiedzi w Kwestionariuszu Relacji Rodzinnych wersji 1 „Moja rodzina” [19]. Ostatnia zmienna - nasilenie depresyjności - również była zmienną interwałową. Jej wskaźnikiem było poczucie badanych dotyczące obecności objawów zaliczanych do symptomów depresyjnych, mierzone jako suma punktów ze wszystkich pytań skali depresji Becka [21]. Skala ta zawiera 21 pytań dotyczących symptomów afektywnych, behawioralnych, motywacyjnych, poznawczych oraz somatycznych depresji [22].

Ponadto za pomocą zastosowanych kwestionariuszy kontrolowano zmienne (np. trudności w funkcjonowaniu, stosowanie używek, obecność chorób somatycznych) mogące mieć potencjalny wpływ na funkcjonowanie psychiczne (np. depresyjność) osób biorących udział w badaniu.

Badania zostały przeprowadzone w 2015 r. w wojewódz twie zachodniopomorskim. Ankiety zostały rozprowadzone wśród uczniów szkół publicznych będących w okresie późnej adolescencji - $\mathrm{w}$ przedziale wiekowym 17-20 lat $(\mathrm{M}=18,64$; $\mathrm{SD}=0,62$ ). Badania miały charakter dobrowolny i anonimowy, a dobór uczestników do grupy był celowy. W badaniu wzięło udział 145 uczniów, jednak ostatecznie analizie statystycznej za pomocą programu SPSS Statistics 22.0 zostały poddane wyniki 120 osób. Uczestnicy w badania wchodzili w skład grup porównawczych z uwagi na typ rodziny, w której się wychowują. W celu weryfikacji założonych hipotez wybrano dwa modele badawcze - model quasi-eksperymentalny pozwalający badać różnice między naturalnie wyodrębnionymi grupami młodzieży z dwóch typów rodzin oraz korelacyjny oparty na współczynniku korelacji liniowej r-Pearsona, co zostało podyktowane charakterystyką zmiennych mierzonych na skali interwałowej. Istotność różnic międzygrupowych dla danych niezależnych sprawdzano przy zastosowaniu parametrycznego testu t-Studenta dla grup niezależnych. Do opracowania zebranych danych i weryfikacji wszystkich hipotez statystycznych przyjęto minimalny poziom istotności $\alpha=0,05$.

\section{WYNIKI}

Z uzyskanych danych wynika, że w grupie osób z rodzin pełnych nasilenie depresyjności jest niewielkie i mieści się w przedziale normy. W zakresie percepcji relacji rodzinnych mierzonych na skali stenowej wymiar komunikacji, spójności oraz tożsamości osiągnął poziom przeciętny, co wskazuje na umiarkowaną satysfakcję z procesu komunikowania, jakości wzajemnych relacji interpersonalnych oraz identyfikacji ze wspólnotą, jaką jest rodzina. Jedynie w przypadku wymiaru autonomii wynik osiągnął wysoki poziom, co świadczy o dużej satysfakcji badanych z poziomu kontroli systemu rodzinnego nad jego członkami.

W grupie młodzieży z rodzin niepełnych nasilenie depresyjności znajduje się w przedziale wskazującym na lekki stopień zaburzenia. W zakresie percepcji relacji rodzinnych mierzonych na skali stenowej wymiar komunikacji, spójności oraz tożsamości rodzinnej osiągnął poziom niski, co wskazuje na występujące chłodne i sztywne relacje interpersonalne oraz brak przywiązania do wartości i tradycji rodzinnych. W przypadku wymiaru autonomii wynik osiągnął poziom przeciętny, co świadczy o umiarkowanej satysfakcji badanych $\mathrm{z}$ doświadczanej autonomii w rodzinie niepełnej.

Badanie wykazało, że wszystkie wymiary percepcji relacji rodzinnych istotnie różnicują obie grupy. W grupie młodzieży $\mathrm{z}$ rodzin pełnych percepcja poziomu komunikacji $(\mathrm{M}=6,07$; $S D=2,03)$, spójności ( $M=6,07 ; S D=2,25)$, autonomii $(M=7,30$; $\mathrm{SD}=1,59)$ i tożsamości $(\mathrm{M}=5,80 ; \mathrm{SD}=1,95)$ jest większa niż percepcja poziomu komunikacji ( $M=4,87$; $S D=1,84)$, spójności $(\mathrm{M}=4,88 ; \mathrm{SD}=1,85)$, autonomii $(\mathrm{M}=6,68 ; \mathrm{SD}=1,72)$ i tożsamości $(\mathrm{M}=4,72 ; \mathrm{SD}=1,64) \mathrm{w}$ grupie młodzieży z rodzin niepełnych. Uzyskane parametry przedstawiono w tabeli 1.

Wykonane analizy potwierdziły również hipotezę mówiącą o istnieniu różnicy w zakresie nasilenia depresyjności pomiędzy obiema grupami. Dzięki analizie testem parametrycznym wykazano, że młodzież z rodzin pełnych $(\mathrm{M}=8,33$; $\mathrm{SD}=8,12)$ przejawia istotnie statystycznie mniejszy poziom nasilenia depresyjności niż młodzież z rodzin niepełnych $(\mathrm{M}=13,38$; $\mathrm{SD}=9,06$ ) - tabela 2 .

Na podstawie rozważań wysunięto również hipotezę na temat istnienia związków pomiędzy percepcją wybranych wymiarów relacji rodzinnych a nasileniem depresyjności u młodzieży z rodzin pełnych. W tabeli 3 przedstawiono wyniki analiz dotyczących powyższych zmiennych.

Wszystkie uzyskane wyniki osiągnęły poziom istotności statystycznej, co pozwoliło na przyjęcie weryfikowanej hipotezy. Depresyjność koreluje ujemnie ze wszystkimi wymiarami percepcji relacji rodzinnych - niskim wartościom komunikacji, spójności, autonomii i tożsamości rodzinnej towarzyszą wysokie wartości depresyjności.

Wyniki analizy statystycznej weryfikującej hipotezę dotyczącą istnienia związku pomiędzy percepcją wybranych 
TABELA 1. Wyniki testu istotności różnic międzygrupowych dla percepcji poszczególnych wymiarów relacji rodzinnych

\begin{tabular}{|c|c|c|c|c|c|c|c|}
\hline \multirow{2}{*}{ Zmienna } & \multicolumn{2}{|c|}{$\begin{array}{l}\text { Grupa młodzieży z rodzin pełnych } \\
\qquad(n=60)\end{array}$} & \multicolumn{2}{|c|}{$\begin{array}{l}\text { Grupa młodzieży z rodzin niepełnych } \\
\qquad(\mathrm{n}=60)\end{array}$} & \multicolumn{3}{|c|}{ Test istotności różnic t-Studenta } \\
\hline & $M$ & SD & $M$ & SD & $T$ & Df & $p$ \\
\hline Komunikacja & 6,067 & 2,0325 & 4,867 & 1,8362 & 3,393 & 116,804 & 0,001 \\
\hline Spójność & 6,067 & 2,2464 & 4,883 & 1,8512 & 3,149 & 113,841 & 0,002 \\
\hline Autonomia & 7,300 & 1,5870 & 6,683 & 1,7222 & 2,040 & 117,221 & 0,044 \\
\hline Tożsamość & 5,800 & 1,9467 & 4,717 & 1,6374 & 3,299 & 114,634 & 0,001 \\
\hline
\end{tabular}

TABELA 2. Wyniki testu istotności różnic międzygrupowych dla zmiennej depresyjność

\begin{tabular}{|c|c|c|c|c|c|c|c|}
\hline \multirow{2}{*}{ Zmienna } & \multicolumn{2}{|c|}{$\begin{array}{l}\text { Grupa młodzieży z rodzin pełnych } \\
\qquad(n=60)\end{array}$} & \multicolumn{2}{|c|}{$\begin{array}{l}\text { Grupa młodzieży z rodzin niepełnych } \\
\qquad(n=60)\end{array}$} & \multicolumn{3}{|c|}{ Test istotności różnic t-Studenta } \\
\hline & $M$ & SD & $M$ & SD & $T$ & Df & $\mathrm{p}$ \\
\hline Depresyjność & 8,333 & 8,1233 & 13,383 & 9,0556 & $-3,215$ & 116,634 & 0,002 \\
\hline
\end{tabular}

TABELA 3. Korelacje pomiędzy percepcją poszczególnych wymiarów relacji rodzinnych a nasileniem depresyjności u młodzieży z rodzin pełnych

\begin{tabular}{|c|c|c|c|c|c|}
\hline & Zmienna & Komunikacja & Spójność & Autonomia & Tożsamość \\
\hline \multirow{3}{*}{ Depresyjność } & korelacja Pearsona & $-0,608^{*}$ & $-0,595^{*}$ & $-0,393^{*}$ & $-0,480^{*}$ \\
\hline & istotność (dwustronna) & 0,000 & 0,000 & 0,002 & 0,000 \\
\hline & & & $\mathrm{n}=60$ & & \\
\hline
\end{tabular}

* korelacja jest istotna na poziomie 0,01 (dwustronnie)

TABELA 4. Korelacje pomiędzy percepcją poszczególnych wymiarów relacji rodzinnych a nasileniem depresyjności u młodzieży z rodzin niepełnych

\begin{tabular}{|c|c|c|c|c|c|}
\hline & Zmienna & Komunikacja & Spójność & Autonomia & Tożsamość \\
\hline \multirow[b]{2}{*}{ Depresyjność } & korelacja Pearsona & $-0,493^{*}$ & $-0,323^{\star *}$ & $-0,518^{*}$ & $-0,213$ \\
\hline & istotność (dwustronna) & 0,000 & 0,012 & 0,000 & 0,102 \\
\hline
\end{tabular}

* korelacja jest istotna na poziomie 0,01 (dwustronnie); ${ }^{*}$ korelacja jest istotna na poziomie 0,05 (dwustronnie)

wymiarów relacji rodzinnych a nasileniem depresyjności u młodzieży pochodzącej z rodzin niepełnych przedstawiono w tabeli 4.

Badanie wykazało istotność statystyczną współczynników korelacji dla trzech zmiennych: komunikacji, spójności oraz autonomii. Współczynnik korelacji dla związku tożsamości z nasileniem depresyjności okazał się nieistotny statystycznie, co wskazuje, że percepcja tożsamości rodzinnej u adolescentów z rodzin niepełnych nie wiąże się z nasileniem odczuwanej przez nich depresyjności. W odniesieniu do pozostałych istotnych statystycznie związków współczynniki korelacji przyjmują kierunek ujemny, podobnie jak w przypadku grupy młodzieży z rodzin pełnych.

\section{DYSKUSJA}

W niniejszej pracy badawczej przypuszczano, iż zachodzą różnice pomiędzy młodzieżą z rodzin pełnych a młodzieżą $\mathrm{z}$ rodzin niepełnych w zakresie percepcji relacji rodzinnych oraz nasilenia depresyjności. Otrzymane wyniki potwierdziły słuszność tych hipotez. Młodzież z rodzin pełnych osiąga wyższe wyniki w zakresie percepcji wszystkich wymiarów relacji rodzinnych oraz niższe nasilenie depresyjności niż ich koledzy z rodzin niepełnych. Wyniki te są spójne z tradycyjnymi koncepcjami psychologicznymi, które zakładają, iż obecność dwojga rodziców tworzy stabilne, a jednocześnie elastyczne środowisko wychowawcze, które w lepszy sposób zaspokaja psychospołeczne potrzeby dorastających potomków, a pośrednio zapobiega zaburzeniom na tle emocjonalnym $[23,24]$.

Adolescenci wychowujący się w pełnym środowisku rodzinnym wysoko oceniają stopień autonomii w rodzinie, są usatysfakcjonowani poziomem kontroli domowników, odczuwają tolerancję systemu dla ich indywidualnych potrzeb i dróg rozwoju, która jest dozowana stosownie do kompetencji i wieku. W tych domach $\mathrm{w}$ racjonalny sposób akceptuje się prywatność, niezależność i prawo do bycia sobą, a dorastające osoby są zachęcane do samodzielnego rozwiązywania problemów i brania odpowiedzialności za swoje decyzje. Mniejszą satysfakcję z doświadczanej autonomii w domu rodzinnym deklarują zaś ich rówieśnicy z rodzin niepełnych, gdyż częściej spotykają się oni z ograniczeniem swobody działania. Być może wynika to z większej tendencji niepełnego sytemu rodzinnego do zachowania stałości struktury wobec zbliżających się zmian związanych z cyklem życia rodziny i dorastaniem nastolatka przygotowującego się do opuszczeniem domu. Samotni rodzice mogą nagradzać posłuszeństwo adolescenta, a tym samym wzmacniać jego zależność z obawy przed zaburzeniem homeostazy rodzinnej [25]. 
Młodzież z rodzin niepełnych nisko ocenia stopień komunikacji pomiędzy domownikami, podczas gdy ich rówieśnicy z rodzin pełnych są bardziej usatysfakcjonowani z procesu porozumiewania się. Adolescenci w rodzinach niepełnych częściej percypują niekonstruktywny sposób dyskusji oraz sztywność komunikacji, przejawiającą się w ignorowaniu stanowiska innych domowników przez osobę dysponującą władzą. W takim środowisku rzadko dochodzi do wypracowania zadowalającego kompromisu, a częściej do narzucania przez opiekuna własnego punktu widzenia. Ponadto występuje mniejsza niż w rodzinach pełnych gotowość do wzajemnej akceptacji czy zrozumienia. Przyjmując, że niska jakość komunikacji jest odzwierciedleniem jakości więzi w rodzinach niepełnych, stosunki te rzadko będą przyjmowały formę partnerską. Prawdopodobnie w rodzinach niepełnych, gdzie ciężar wychowania spoczywa tylko na jednym opiekunie, rola osoby sprawującej władzę ulega usztywnieniu i utrudnia modyfikację sposobu porozumiewania się, który byłby dostosowany do etapu rozwojowego potomka, co również może być rozpatrywane z punktu widzenia potrzeby utrzymania stabilności systemu [25].

W przeciwieństwie do adolescentów dorastających w rodzinach pełnych, którzy deklarują przeciętny stopień satysfakcji ze wzajemnych relacji interpersonalnych, młodzież z rodzin niepełnych nisko percypuje spójność domowników, co oznacza że wzajemne relacje uważa za chłodne i sztywne, a panującą $\mathrm{w}$ domu atmosferę za niesprzyjającą ujawnianiu pozytywnych uczuć. Członkowie tych rodzin są zamknięci w sobie, a przez to rzadko udzielają sobie wzajemnego wsparcia. Częściej niż $\mathrm{u}$ adolescentów $\mathrm{z}$ rodzin pełnych dochodzi do nieumiejętnego rozwiązywania konfliktów rodzinnych poprzez zaprzeczanie lub ich ignorowanie, co wtórnie prowadzi do tworzenia koalicji i pogorszenia relacji. Dane te współbrzmią ze wcześniej opisanymi nierównościami w relacjach członków rodzin niepełnych, w których dominuje wzmożona kontrola rodzicielska, zakłócająca satysfakcjonujący dla wszystkich domowników podział władzy. Brak spójnych relacji rodzinnych w pewnym stopniu tłumaczy, dlaczego adolescenci z takich środowisk przejawiają wzmożony niepokój oraz potrzebę separacji od rodziny i poszukiwania wsparcia u rówieśników, a także dlaczego częściej cierpią na zaburzenia natury psychicznej [26].

Pochodząca z niepełnych rodzin młodzież ocenia poziom tożsamości rodzinnej jako niski, co świadczy o braku przywiązania domowników do wartości, tradycji i zasad, w przeciwieństwie do młodzieży z rodzin pełnych, która silniej identyfikuje się ze wspólnotą, jaką jest rodzina. Adolescenci z niepełnego środowiska rodzinnego mają poczucie, że w rodzinie nie ma jednoznacznie określonych zasad, które mogłyby być płaszczyzną wartościowania różnorodnych wydarzeń pozarodzinnych. Mniejsze poczucie tradycjonalizmu oznacza większy liberalizm oraz rozchwianie wartości moralnych, religijnych czy obyczajowych. Doniesienia te potwierdzają dotychczasowe rozważania, iż rodziny niepełne w mniejszym stopniu zaspokajają potrzeby o charakterze społeczno-duchowym adolescentów, przez co być może sprzyjają realizowaniu tychże pragnień w środowisku pozarodzinnym, głównie rówieśniczym [27].
Przeprowadzone badanie ujawniło również różnice międzygrupowe w zakresie nasilenia depresyjności. U młodzieży z rodzin niepełnych było ono wyższe i wskazywało na lekki stopień zaburzenia, podczas gdy u młodzieży z rodzin pełnych natężenie objawów depresyjnych pozostało w granicach normy. Dane potwierdzają zatem doniesienia z zagranicznych i polskich badań, iż pochodzenie z rodziny niepełnej jest związane z wyższym poziomem symptomów depresyjnych i może być traktowane jako znaczący czynnik ryzyka dla tego zaburzenia $[6,7,15]$. Prawdopodobnie zerwanie emocjonalnych więzi $\mathrm{z}$ rodzicem wskutek jego opuszczenia lub śmierci jest tak znaczącą startą, iż buduje nadwrażliwość na zranienia, a jednocześnie zmusza jednostkę do konfrontacji z większą liczbą stresujących doświadczeń życiowych. Dodatkowo występujące w rodzinach niepełnych nieprawidłowe relacje interpersonalne mogą w długoterminowej perspektywie zmniejszać poczucie bezpieczeństwa, kompetencji i własnej wartości, a w konsekwencji predysponować do podatności na zaburzenia w zakresie zdrowia psychicznego [28].

W trakcie badań założono również, że zachodzi związek pomiędzy percepcją wybranych wymiarów relacji rodzinnych a nasileniem depresyjności u młodzieży z obu typów rodzin. Badania potwierdziły istnienie ujemnych związków pomiędzy percepcją wszystkich wymiarów relacji rodzinnych a nasileniem depresyjności w odniesieniu do adolescentów z rodzin pełnych. Zatem im bardziej relacje rodzinne są postrzegane jako sztywne w komunikatach, pozbawione wzajemnego wsparcia, kontrolujące i ograniczające prywatność oraz pozbawione fundamentalnych wartości i zasad, tym większe jest nasilenie objawów depresyjnych, co pozostaje spójne z wynikami badań uzyskanych przez Radziwiłłowicz i wsp. [15] oraz Trzęsowską-Gresztę i wsp. [18]. W przypadku młodzieży z rodzin niepełnych słuszność hipotezy potwierdziła się jedynie częściowo w odniesieniu do takich wymiarów relacji rodzinnych jak komunikacja, spójność i autonomia, podczas gdy wymiar tożsamości nie osiągnął związku istotnego statystycznie z nasileniem depresyjności. Może to oznaczać, że u młodzieży z rodzin niepełnych fakt braku przywiązania w rodzinie do tradycyjnych wartości pozostaje bez znaczenia dla nasilenia symptomów depresyjnych. Jest to wynik, który może przemawiać za niewielką wagą niepełnego środowiska rodzinnego przy współtworzeniu tożsamości młodego człowieka i jego psychicznego zdrowia, na rzecz środowiska rówieśniczego, które w tym okresie rozwojowym zaczyna pełnić dominującą rolę w kreowaniu postaw i określaniu zachowań społecznych czy preferowanych wartości [29].

Dla pozostałych istotnych statystycznie związków zmiennych percepcji relacji rodzinnych z nasileniem depresyjności u adolescentów z rodzin niepełnych korelacje przyjmują kierunek ujemny, podobnie jak w przypadku korelacji w grupie młodzieży z rodzin pełnych. Może to sugerować, iż bez względu na to, czy w środowisku domowym opiekę sprawuje jeden czy oboje rodziców, prawidłowe relacje rodzinne wiążą się z mniejszym nasileniem objawów depresyjnych, a więc lepszym zdrowiem psychicznym adolescentów. 


\section{WNIOSKI}

Potwierdzono istnienie różnic między młodzieżą z rodzin pełnych a młodzieżą z rodzin niepełnych w zakresie percepcji wybranych wymiarów relacji rodzinnych oraz w zakresie nasilenia depresyjności, a także związek pomiędzy percepcją wybranych wymiarów relacji rodzinnych a nasileniem depresyjności u młodzieży z rodzin pełnych. W przypadku młodzieży z rodzin niepełnych związek został potwierdzony jedynie częściowo w zakresie trzech wymiarów relacji: komunikacji, spójności i autonomii. Wszystkie potwierdzone korelacje wykazywały kierunek ujemny w obu grupach, a więc im bardziej obniżona komunikacja, spójność, autonomia i tożsamość rodzinna, tym większe nasilenie odczuwanej przez adolescenta depresyjności. Uzyskane wyniki dowiodły różnic międzygrupowych w zakresie nasilenia depresyjności na niekorzyść adolescentów z rodzin niepełnych, który osiągnął poziom zaburzenia depresji w stopniu lekkim. Dzięki badaniom zaobserwowano również znaczące różnice międzygrupowe w zakresie percepcji relacji rodzinnych; u młodzieży z rodzin niepełnych - wymiar komunikacji, spójności, autonomii i tożsamości był oceniany niżej, a więc mniej korzystnie niż przez adolescentów z rodzin pełnych.

Uzyskane dane pozwalają na wysnucie wniosku, iż nawet w okresie adolescencji, gdy wzrasta potrzeba niezależności i dystansu od rodziny, a tym samym środowisko rodzinne zaczyna mieć mniejsze znaczenie dla dobrostanu psychicznego młodzieży, brak prawidłowych relacji z domownikami pozostaje silnie związany z poczuciem depresyjności. Wzmacnia to pośrednio założenie traktujące zaburzenie u jednego z członków rodziny za objaw manifestujący nieprawidłowości występujące w całym systemie.

Otrzymane wnioski pozwalają na praktyczne ich wykorzystanie przez osoby konstruujące programy profilaktycznych oddziaływań adresowanych do młodzieży, mające na celu zapobieganie zaburzeniom depresyjnym, oraz warsztaty umiejętności rodzicielskich skoncentrowane na psychoedukacji w zakresie budowania prawidłowych relacji w systemie rodzinnym, które przyczyniłyby się do zapobiegania rozwojowi niekorzystnych wzorców, a wzmacniałyby prawidłowe praktyki. Szczególnym wsparciem psychospołecznym powinno się obejmować rodziców samotnie wychowujących dorastające potomstwo, aby wzmocnić ich świadomość co do znaczenia jakości relacji w systemie rodzinnym dla zachowania zdrowia psychicznego ich członków.

\section{PIŚMIENNICTWO}

1. Braun-Gałkowska M. Psychologia domowa. Olsztyn: Warmińskie Wydawnictwo Diecezjalne; 1990.

2. Janicka I, Liberska H, editors. Psychologia rodziny. Warszawa: PWN; 2014.

3. Plopa M. Psychologia rodziny. Teoria i badania. Elbląg: Wyd. EUHE; 2005.
4. Greszta E. Depresja wieku dorastania. Zachowania rodziców jako czynnik ochronny lub czynnik ryzyka depresji u dorastających dzieci. Warszawa: Wyd. SWPS Academica; 2006.

5. Hammen C. Depresja. Gdańsk: GWP; 2006.

6. Brown SL. Family structure transitions and adolescent well-being. Demography 2006;43(3);447-61.

7. Cavanaugh SE. Family structure history and adolescent adjustment. J Family Issues 2008;29:944-80.

8. Bomba J, Modrzejewska R. Prospektywne badanie dynamiki depresji u młodzieży w późnej fazie dorastania. Psychiatr Pol 2006;4:695-706.

9. Bomba J. Depresja młodzieńcza. In: Namysłowska I, editor. Psychiatria dzieci i młodzieży. Warszawa: PWZL; 2004. p. 266-79.

10. Rabe-Jabłońska J. Zaburzenia afektywne u dzieci i młodzieży. In: Namysłowska I, editor. Psychiatria dzieci i młodzieży. Warszawa: PZWL; 2004. p. 324-35.

11. Pużyński S, Wciórka J. Klasyfikacja zaburzeń psychicznych i zaburzeń zachowania w ICD-10. Kraków: Wyd. Med. Vesalius i Instytut Psychiatrii i Neurologii; 2000.

12. Link-Dratkowska E. Depresja dzieci i młodzieży - podejście poznawczo-behawioralne. Teoria i terapia. Psychiatria 2011;8(3):84-90.

13. Rabe-Jabłońska J. Depresja u dzieci i młodzieży. Aktualne poglądy na etiologię, diagnozowanie, przebieg i leczenie. Psychiatr Psychol Klin Dzieci Młodzieży 2001;1:7-25.

14. Namysłowska I, Bronowska Z. Leczenie zaburzeń depresyjnych dzieci i młodzieży. Psychiatr Psychol Klin Dzieci Młodzieży 2000;1:45-57.

15. Radziwiłowicz W, Szadziszewska B, Sulska E. Depresja młodzieży w kontekście funkcjonowania rodziny. In: Radziwiłłowicz W, Sumiła A, editors. Psychopatologia okresu dorastania: wybrane zagadnienia. Kraków: Oficyna Wydawnicza Impuls; 2006. p. 123-74.

16. Carr A. Depresja i próby samobójcze młodzieży. Sposoby przeciwdziałania i reagowania. Gdańsk: GWP; 2004.

17. Kendall PC. Zaburzenia okresu dzieciństwa i adolescencji. Mechanizmy zaburzeń i techniki terapeutyczne dla praktyków i rodziców. Gdańsk: GWP; 2004.

18. Trzęsowska-Greszta E, Sikora R, Kopeć WM. Typ relacji w rodzinie a ryzyko depresji w fazie dorastania - $w$ ujęciu teorii systemowej rodzin. Kwartalnik Naukowy Towarzystwa Uniwersyteckiego Fides Et Ratio 2014;3(19):186-203.

19. Plopa M, Połomski P. Kwestionariusz Relacji Rodzinnych. Wersja dla młodzieży. Warszawa: Wyd. Vizja Press \& IT; 2010.

20. Radziwiłłowicz W. Depresja u dzieci i młodzieży. Analiza systemu rodzinnego - ujęcie kliniczne. Kraków: Oficyna Wydawnicza Impuls; 2011.

21. Parnowski T, Jernajczyk W. Inwentarz Depresji Becka w ocenie nastroju osób zdrowych i chorych na choroby afektywne (ocena pilotażowa). Psychiatr Pol 1977;11:417-25.

22. Pużyński S. Choroby afektywne nawracające. In: Bilikiewicz A, Pużyński S, Rybakowski J, Wciórka J, Psychiatria. Tom II. Wrocław: Urban \& Partner; 2002. p. 343-415.

23. Jodłowska M. Obraz rodziny w opiniach dzieci z rodzin dysfunkcjonalnych. Komunikat z badań. Roczniki Socjologii Rodziny 1999;11:183-95.

24. Walęcka-Matyja K. Zachowania społeczne młodzieży a uwarunkowania rodzinne i osobowościowe. Łódź: Wydawnictwo Uniwersytetu Łódzkiego; 2009.

25. de Barbaro B, editor. Wprowadzenie do systemowego rozumienia rodziny. Kraków: Collegium Medicum UJ; 1999.

26. Grochocińska R. Specyficzna problematyka życia rodziny rozbitej. In: Rostowska T, Rostowski J, editors. Rodzina - rozwój - praca. Wybrane zagadnienia. Łódź: WSI; 2002. p. 73-83.

27. Bardziejewska M. Okres dorastania. Jak rozpoznać potencjał nastolatków. In: Brzezińska AI, editor. Psychologiczne portrety człowieka. Praktyczna psychologia rozwojowa. Gdańsk: GWP; 2005. p. 345-77.

28. Dyczewski L. Rodzina, społeczeństwo, państwo. Lublin: Wyd. Towarzystwa Naukowego KUL; 1994.

29. Obuchowska I. Adolescencja. In: Harwas-Napierała B, Trempała J, editors. Psychologia rozwoju człowieka. Tom 2. Warszawa: PWN; 2000. p. 163-97. 